\title{
PROBLEMS OF OLDER WORKERS ON THE LABOUR MARKET
}

\author{
Pavel Breinek ${ }^{1}$ \\ ${ }^{1}$ Department of Economics, Faculty of Business and Economics, Mendel University in Brno, Zemědělská 1, 61300 \\ Brno, Czech Republic
}

\begin{abstract}
BREINEK PAVEL . 2018. Problems of Older Workers on the Labour Market. Acta Universitatis Agriculturae et Silviculturae Mendelianae Brunensis, 66(4): 1073-1084.

This article focuses on position of older workers on labour market. It tries to identify and shortly describe the main factors affecting chances of older workers to get and keep a job. There are many approaches how to evaluate the opportunities and obstacles faced by older workers. On the basis of review of literature this paper points to significant problems that population ageing can bring to labour market. The differences between changes in productivity and changes in earnings might lead to reduction of employment of older workers. Technological progress or structural changes in industrial economies leads to other difficulties associated with ageing. Both employment and hiring of older workers are influenced by institutional arrangement. The future reforms should be aimed at improving flexibility of the labour market or eliminating stickiness of wages. The attention should be also paid to pension system and social security system. Finally, better education, training and health might help to delay the retirement as well.
\end{abstract}

Keywords: ageing, delayed compensation, earnings, labour market flexibility, labour productivity, retirement, technological process, training

\section{INTRODUCTION}

Population ageing in many industrial countries is likely to have many social, political and economic effects. Economic growth in the long term or sustainability of public finance are, for example, priority topics of interest. Keeping older workers in the workforce could be necessary to reduce negative effects of ageing on future prosperity. Both how to motivate older employees to work longer and how to stimulate firms to hire and employ older workers are seen as important issues. The drop in labour supply can be suppressed by institutional changes creating incentives to prevent abrupt retirement and extend working life. The institutional arrangement should also bring the opportunities for older worker after displacement. The success of adopted measures is associated with understanding the factors that influence the decision making of workers and firms.

The goal of the article is to shortly describe main factors determining both employing and hiring of older workers. On the basis of literature review this paper tries to identify relevant risks and restrictions for older workers on the labour market. However, there are many potential factors influencing chances to get and keep a job. The review of studies make it possible to choose the most important of them. The article focuses on the relationship between productivity and wages and its changes over working time. Some significant determinants of productivity as well as wages are highlighted too. This paper is also interested in position of older workers on the labour markets and improvement of their job prospects. Pointing to obstacles and opportunities for older workers can help to facilitate the discussion about future arrangement of labour market.

There are many econometric studies trying to quantify the effects of ageing on both productivity and earnings or trying to reveal the significance of varied factors determining the status of older workers on labour market. Because of many shortages of these studies we have decided to 
compare different approaches and findings of selected research papers. Moreover, this article not only summarizes factors affecting prospects of senior workers but also distinguishes between obstacles (or opportunities) for older workers and firms. Finally, we use OECD statistics to show the participation of older workers on labour market in some European countries.

\section{PRODUCTIVITY AND WAGES OF OLDER WORKERS}

Presumed gap between productivity and wage seems to be serious reason for firms not to hire or retain older workers. But measuring the effects of ageing on productivity is not easy task. Unfortunately, the suitable measure of productivity is missing as well as there is a lack of relevant data. Sample selection problem could also matter. As a result, empirical studies focusing on the relationship between age and productivity are not so abundant and the findings are ambiguous. Generally, there are three possible ways how to measure productivity.

First, workers' performance is often estimated by indirect measures like supervisors' ratings. The findings don't indicate any systematic relationship between age and workers' productivity (Skirbekk, 2003). The second approach to productivity is based on estimations of contribution of individual age cohorts of workers to firms' output. The studies usually suggest lower productivity of older workers (Aubert and Crépon, 2007; Skirbekk, 2003). Workers' marginal effect on firms' value added can be used as the third measure of individual productivity. Inverted U-shaped profile of relationship between age and productivity is indicated by related employer-employee studies (Skirbekk, 2003). a problem of these micro-level approaches is dependence of productivity on complex interaction with other workers and other factors of production or technology (Werding, 2008). Generally, while individual studies often find relatively strong relationship between age and productivity, studies both covering data across individual studies and reflecting results to the whole population don't confirm any systematic relationship (Belbase and Sanzenbacher, 2016). ${ }^{1}$

The employment of the elderly is affected not only by changes in their productivity but also by changes in their earnings. There are several studies trying to estimate both the relationship between age and productivity and the relationship between age and wages. Medoff and Abraham (1980) suggest that greater experience moves managerial and professional employees toward the upper tail of earnings distribution. But it does not move them toward the upper tail of relevant performance distribution. The first study trying to compare age-productivity and age-wage profile was written by Hellerstein and Neumark (1995). Authors find that for unskilled or less skilled workers estimated earnings and productivity profiles are upward sloping and reflect each other closely. However, according to Hellerstein and Neumark (2004) both the wage and productivity profiles are rising and concave but the wage profile is steeper. The productivity is also likely to decrease faster than wage after 55. Finally, Hellerstein, Neumark and Troske (1999) find that the growth rate of both productivity and earnings is the same for older workers. Thus older workers have higher earnings because of their higher productivity.

However, Hægeland and Klette (1999) argue that for more experienced workers the wage premium exceeds the productivity premium. Dostie (2006, 2011) suggests that both wage and productivity profiles are concave but wages are diminishing slower than productivity after age of 55. Aubert and Crépon (2007) mention the older study by Crépon, Deniau and Perez-Duarte from 2001 in which the difference between older workers' and younger workers' productivity is smaller than the difference in their wages. But according to Aubert and Crépon the evidence of overpaid of older workers is inconclusive.

Van Ours (2009) argues that physical productivity is likely to decrease after age 40, while mental productivity tend to be stable after age 50. However, he doesn't admit an increasing pay-productivity gap at higher ages. Similarly, Van Ours and Stoeldraijer (2011) find that productivity is (inverted) U-shaped with age but they don't confirm age-related productivity pay gap. Mahlberg et al. (2013) suggest that ageing workforce couldn't be associated with drop in productivity and the evidence of unjustified wage payments doesn't exist. ${ }^{2}$

There are some theoretical as well as empirical evidence confirming the decline of productivity with age, particularly in case of manual workers. Although conventional wisdom emphasizes that older workers are usually overpaid, the empirical studies don't offer unambiguous answer. Because age-productivity profile and age-wage profile of individual worker are changing differently

1 Aiyar, Ebeke and Shao (2016) also remind that workers with basic jobs (i.e. factory workers) tend to be less productive as they age, while productivity increases with age in occupation as lawyers, professors, managers or medical doctors. And commercial clerks or electronic engineers belong to age-neutral occupation. Thus the aggregate effects of ageing on productivity depend on industrial structure of economy.

2 There are also studies focusing only on relationship between ageing and productivity. Tang and MacLeod (2006) indicate lower productivity of workers aged 55 and over compared to younger workers. Similarly, according to Lallemand and Rycx (2009) the higher share of older workers affects negatively firms' productivity. 
with age, the older workers might be blamed for the gap between productivity and wage. However, other studies don't indicate an age related pay-productivity gap. Thus the difference between the increase in productivity and increase in wage might not exists.

Actually, the development of wages doesn't need to equal to changes in productivity. The analysis of relationship between age and earnings is usually based on Becker's human capital model and Mincerian wage equations which explains earnings as a function of educational attainments, job experience or age, and a number of socio-economic background characteristics. Models generally suggests that wages increase from the beginning of working life until the workers are in their 40's and they start to decline due to human capital depreciation (Dostie, 2006; Werding, 2008 and Gordo and Skirbekk, 2013).

The theory of human capital explains the increase in wages with experience by acquisition of general skills during the working life. The increasing productivity of workers is the reason for positively sloped experience-wage profiles. Gordo and Skirbekk (2013) also argue that acquisition of skills and increase in productivity are sometimes considered as a result of changes in work tasks. In other words, if older workers evince both the rise in cognitively intense tasks and tasks demanding fluid cognitive abilities and if these tasks are associated with higher reward, the higher wages of older workers could be justified. European commission (2006) mentions Becker's approach that companies pay for firm specific training and it could lead to higher wages than productivity at young ages. The reverse should be true for older workers. If the employee is unable to sell the specific skills to another companies, the firm usually takes responsibility for both benefits and cost. Thus wage and marginal productivity couldn't be the equal in every moment but could equal over the working life.

Similarly, Lazear's theory of deferred compensations suggests that workers and firms prefer long-term relationship in which the worker receive initially lower wage than the value of the marginal productivity. On the other side, older workers earn more than their marginal product (with the company pension as final payoff) and are relatively overpaid. Such delayed-compensation contracts could both encourage employees' lifetime work effort (or productivity) and discourage the worker from shirking. It might also lower firms' need to train new workers, rise junior workers' loyalty or alleviate monitoring problems (Van Ours and Stoeldraijer, 2011; Heywood and Siebert, 2009 or Skirbekk, 2003; Heywood and Jirjahn, 2016).
There are also other reasons for differences between wage and productivity. In addition to individual contribution to the firms' value-added, the wages usually depend on various factors. Uncertainty about new workers productivity, delayed payment contracts or labour unions might play also an important roles (Skirbekk, $2008)^{3}$. Incentive-compatible wages, forced saving mechanisms, efficiency wages, minimization of turnover related costs, specific training or wage discrimination can be other wage determinants (Dostie, 2006). Whereas perfect competition in labour market eliminates the differences between wages and marginal productivity, the existence of labour market institutions, imperfect information or costly monitoring of productivity weakens the relationship between age and productivity and leads to age-related pay-productivity gap (Van Ours and Stoeldraijer, 2011).

Particularly, models of efficiency wages predict the differences between wage and productivity related to age from various reasons. First, the uncertainty about productivity of newly employed workers stimulates firms to pay relatively lower wages to younger workers. Second, upward sloping wage profile might both encourage working effort of employees and reduce incentives to give a notice. Third, because fluctuation is costly and workers are risk averse, working relationships tend to last for a longer period. If older workers receive higher earnings as a reward for previous productivity, the loyalty of younger worker can rise. Fourth, postponed wages can serve as a self-selection tool to discourage the workers from leaving the firm. These models can contribute to explanation why productivity exceeds wage in the beginning of workers carrier and the opposite holds in the end of working life (European Commission, 2006).

\section{FACTORS DETERMINING PRODUCTIVITY OF OLDER WORKERS}

Individual productivity can change during the working life for reasons such as differences in experience, depreciation of knowledge or age-related trends in physical and mental capabilities (Werding, 2008). Longer experience and higher levels of job knowledge can lead to stable or increasing performance of older workers, while deterioration of relevant skills and decrease in cognitive abilities can reduce individual productivity. There are empirical findings confirming decrease (or absence of growth) in productivity after the age of 50 .

European commission (2006) argues that economic depreciation occurs when people forget what they have learnt and gained skills become outdated. If

3 Von Ours (2009) or Von Ours and Stoeldraijer (2011) argue that greater care of unions about senior workers and their preferences leads to increase in wage according to seniority. There could be also higher protection of older workers because of employment protection legislation. Thus firms usually don't replace high wage older workers for low wage young workers. Finally, workers should prefer increasing wage profiles instead of flat or decreasing wage profiles of greater monetary value. 
the depreciation is higher than acquiring of new human capital, individual productivity starts to decrease (or stops raising). Thus the age-productivity profile is likely upward sloping until the certain age and thereafter this profile is decreasing (or flat). In other words, older workers have generally longer experience enhancing their productivity but the decline in cognitive abilities can supress their job performance (Carone et al., 2005 and Skirbekk, 2003).

Actually, different cognitive abilities can change over the work life in different ways. There is distinction between "fluid intelligence" and "crystallised intelligence". The fluid cognitive abilities (e.g. processing speed and reasoning or numerical skills and ability to adjust to new situation) tend to strongly decline with age. In contrast, crystallized abilities (e.g. general experience, verbal fluency and vocabulary size) tend to remain more or less stable. The employees engaged in jobs, where problem solving, learning and speed are important, will experience strong decline in their productivity. But employees, where experience and verbal skills play a crucial roles, can see less or no reduction in productivity at the end of their careers (Skirbekk, 2003, Gordo and Skirbekk, 2013 and The Economist, 2009). ${ }^{4}$ Actually, despite a decrease in fluid intelligence most workers are able to retain its productivity. According to Belbase and Sanzebacher (2016) crystallized intelligence can offset declines in fluid intelligence and cognitive reserves (i.e. fluid intelligence that exceeds job demands) can create a buffer for older workers.

The estimation of productivity of older workers also faces the problem of the occupational shifts. While good employees are promoted, less effective workers lose their job or they are demoted (Skirbekk, 2003). Similarly, if there is a low demand for firms' production and no need to hire new workers then econometric studies can find not only low level of production but also higher share of older workers (Aubert and Crépon, 2007). And if the firm facing negative productivity shock which induces firm to fire young workers then productivity decline should be wrongly attributed to the increase in average age of the workforce (Van Ours and Stoeldraijer, 2011).

However, many empirical studies and experience suggest a decline in cognitive and physical abilities with age. But productivity of older workers can be affected by other factors. For example, the scarcity of workers should stimulate innovation in work saving and capital intensive technologies. The Economist (2014) also argues that productivity of older workers can be encourage by better education at any time of life. The older employees are disproportionally more productive if they are disproportionally better educated. And workers with more education tend to work longer because less educated workers are more often engaged in manual jobs. (The ageing could make more difficult to cope with intensive manual work). Moreover, the improvement in health of senior employees can slow down or eliminate decrease in their working performance.

As Van Ours and Stoeldraijer (2011) summarize the productivity is highly individual and sector-specific. Complexity of individual productivity reflects communication skills, information processing speed, strength and endurance, health, self-discipline, flexibility, administrative and strategic capacities, math proficiency, vocabulary size, education, motivation, energy and job experience. The effects of ageing on productivity depends on importance of work experience, physical strength and cognitive abilities for work performance. In other words, different cognitive abilities and physical strength are needed for different jobs.

Actually, the decline in some cognitive abilities, health and physical strength across the life span competes with motivation, experience and managerial skills of older workers. Targeted training programs and better health care can slow down the pace of deterioration of skills required for jobs where problem solving and learning are necessary. Not only assistance to improve age-specific mental abilities and health level but also implemented technology or how the individual skills are used, how the work is organized and how the individual interacts with other workers can influence the work potential of older workers (Van Ours and Stoeldraijer, 2011).

When evaluating the productivity of older workers and their position in labour market, it might be difficult to distinguish the age effect from factors like experience, training or physical capacity in senior age. European commission (2006) emphasizes that relatively lower productivity of older employees doesn't inevitably mean worsening of individual performance. If current younger cohorts have both superior education or trainings and have higher mobility or flexibility then senior workers always face obstacles in labour market.

The other problem of estimating the value added by individual worker and its changes with age can be fact that work is usually practised in teams. Working teams consist of individuals with different backgrounds and experience. Thus it is difficult to classify the contribution of every single employee (National research council, 2012). Börsch-Supan (2013) claims that workers influence productivity of their colleagues. Older employees might devote more time to younger workers and vice versa. In this case, the performance of older workers should be underestimated.

Moreover, Dalen, Henkens and Schippers (2010) argue that comparative advantage of older workers lies in social skills, reliability and commitment, accuracy, and customer-oriented skills. The younger

4 The Economist (2009) points out that employers are persuaded that older workers face the difficulties in acquiring new skills. Thus lower training is offered senior workers. However, Gordo and Skirbekk (2013) argue that cognition is likely strongly correlated with training success and work productivity. 
workers are relatively better in creativity, mental and physical capacity to deal with workload, willingness to learn new skills and adapt to new technology, and flexibility. These qualities also usually have greater weight in the evaluation of the productivity of workers.

On the other side, Heywood and Jirjahn (2016) suggest that age diversity can lead to more conflicts and communication difficulties within teams. (Average age of workers within a team isn't associated significantly with production errors but higher age diversity of team members is associated with increase in errors). ${ }^{5}$ Moreover, older employees might tend to prepare for retirement and try to reduce working hours. If production takes place in teams then according to Blau and Shvydko (2007) absence of a team member can lead to decrease in team productivity.

On the other side, Göbel and Zwick (2013) find that age-specific work requirements, specific equipment in workplaces for old employees and mixed-age working teams increase relative productivity of old employees. Both reduced and flexible working time for old employees or inclusion of old employees in training measures can also play important roles in reducing productivity differences between different age groups. These measures are based on the insight that old and young workers have complementary competencies and capabilities. Skirbekk (2008) argues that targeted training programmes and engagement in complex work tasks can stall the decline in age-related reductions in cognitive abilities.

\section{EMPLOYING OLDER WORKERS}

The mismatch between (potentially) decreasing productivity and higher wages of older workers is likely to worsen the positon of senior workers on the labour market. The firms usually prefer younger workers because the older employees are often too expensive in relation to their productivity. (In other words, if the wages exceeds the productivity, firms lose from hiring older workers.) The relatively lower productivity stimulates employers to rid of older workers if necessary. ${ }^{6}$ They often take advantage of both various types of social security systems and early retirement arrangements. However, because of strict labour market protection for old employees, selective dismissal of older workers can be expansive. Despite many obstacles to dismiss senior workers from employment, the wage-productivity gap reduces their employment opportunities. As a result the senior workers should be excluded from the labour market.

These concerns were partially confirmed by Chan and Stevens (2001) who found that involuntary job loss of older workers is associated with large and lasting reductions in their employment. This is the result of both rates of return to employment after displacement and increased rates of exit from post-displacement jobs. Moreover, the return rates for displaced workers decline with age and post-displacement jobs are often only short-term. Dalen, Henkens and Schippers (2010) suggest that opportunities of older workers to re-enter the labour force after a period of unemployment are limited. And changing jobs or careers at the end of a working life can be difficult too. The negative stereotypes about the abilities and productivity of older workers reduce their employment prospects. Thus, as Daniel and Heywood (2007) mention, many displaced older workers remain unemployed or move into retirement (and represent hidden unemployment) or long-term sickness.

Actually, many firms are reluctant to hire older workers but they are often willing to employ them. ${ }^{7}$ There are two other explanation why employers prefer younger workers. First, job opportunities of older workers could be reduced because of training. Daniel and Heywood (2007) point out that occupations entailing substantial general training tent to be more attractive to younger workers because they can capture returns over more years. Whereas jobs with substantial specific training cause large fixed costs (to the firm) that can be reduced by hiring younger workers. ${ }^{8}$ Thus the firms offering specific training tend to have employees with longer tenure and hire older workers infrequently.

The second reason, why firms employ older workers but not to hire them, is mentioned delayed compensation (or backloading). ${ }^{9}$ Daniel and Heywood (2007) identify years of tenure and having a pension or mandatory retirement as important determinants of hiring smaller share of older workers. If workers are afraid that firm don't abide by the agreement to delay compensation, the firm have to accept the costs of increased compensation and increased shirking. Thus, as Daniel and Heywood argue, delayed compensation is associated

5 However, the effect of age diversity on productivity is ambiguous (see Heywood and Jirjahn (2016)).

6 In other words, risk averse employers are often reluctant to hire older workers because of their higher variation in productivity. Although older workers shouldn't be in general less productive, the productivity of unemployed older workers tends to be lower (Heywood and Jirjahn, 2016).

7 Konle-Seidl (2017) argues that the increase in employment rates of older workers is the result of higher job retention, while job mobility (or hiring) is trivial.

8 If workers share both the costs of training and later return on this investment, the specific training lead to upward-sloping earning profile.

9 The third factor of the poor labour market prospects of older workers seems to be also the age (anti)discrimination law. While it improves the position of employed older workers, it can make more difficult for unemployed workers to get a job (Heywood and Jirjahn, 2016). 
with additional fixed costs and motivates firm to lower costs by hiring younger workers. Moreover, Heywood and Siebert (2009) suggest if deferred pay exceeds marginal productivity (of older workers), the firms would try to minimise costs by mandatory retirement date.

On the other side, according to Heywood and Siebert (2009) shorter employment horizon also means that older workers are less well motivated by delayed compensation. (It discourage the firms from hiring older workers too.) Heywood and Jirjahn (2016) point to difficulties for older workers seeking a new job. They are usually both less motivated by life-cycle profiles and are often paid less than others with similar experience. However, a reduced use of deferred compensation can lead to decrease in share of older workers employed by the firms.

Studies by Daniel and Heywood (2007) and Heywood, Jirjahn and Tsertsvardze (2008) also suggest that both firms offering pensions or employee ownership and firms with steeper wage profile tend to hire fewer older workers. Greater human capital requirements can reduce the opportunity of older worker to get job too. Finally, unionized firms, firms using promotion to generate an internal labour market or firms using dismissal have usually little interest to hire older workers. On the other side, larger firms or firms with larger share of female workers and firms offering profit sharing or paying above negotiated wages are more willing to give a job to older workers. ${ }^{10}$

However, there could be some good reasons for employing older workers. They have not only more job experience and know-how but also better job-match qualities and greater tenure, require less supervising, and generally are more willing to choose non-standard work arrangements such as self-employment (Beach, 2008). Older workers are also associated with higher reliability and better skills (than younger workers) or generally can be more consistent, cautious, and conscientious (Van Ours and Stoeldraijer, 2011). In addition, Gómez and de Cos (2008) concede that senior employees involve lower monitoring costs and have both higher firm specific human capital and more experience learned by working. ${ }^{11}$ Younger workers are associated with new ideas or general human capital covered in formal education. Imperfect substitution between human capital of older and younger workers might be important attribute of future production.
The prospects of older workers on the labour market might be changed by structural changes in an economy. Technological progress is often associated with raising importance of being able to learn and to adjust to new ways of working, while long work experience are losing its relative importance. Skirbekk (2003) points to age-related decrease in the processing speed and in learning capacities that can be seen as a handicap for older workers. According to Gordo and Skirbekk (2013) technological and industrial changes in some developed countries lead to increase in employment in service and ICT related industries and decrease in demand for manual work. Thus especially older manual workers should be less able to adapt to technological changes. Similarly, Van Ours and Stoeldraijer (2011) argue that new technologies and working techniques reduce the need for manual work and raise the demand for high skill workers. Cognitive abilities are becoming more important than physical strength and bodily co-ordination.

As Gordo and Skirbekk (2013) mention, technological progress tends to decrease seniors' productivity and raise risk of job loss. The reduction in seniors' employment level can be the result of both lesser ability of older workers to adopt to technological innovations and their lower benefits from technological improvements in comparison to younger workers. Blau and Shvydko (2007) point to higher exit rate from employment induced by unanticipated acceleration in the rate of technological change. But according to Heywood, Jirjahn and Tsertsvardze (2008) occupational experience of older workers may be useful for a successful implementation of rather incremental technological changes. In this case, firms could be more willing to hire older workers.

Although Lallemand and Rycx (2009) concede that senior worker in ICT firms can be less productive than their younger counterparts their relatively performance can show the signs of improvement. In addition, older computer users usually tend to retire later. However, Heywood, Jirjahn and Tsertsvardze (2008) mention lower hiring rate of older workers in firms requiring the use of computers. Inferior computer skills and firms' reluctance to improve the skills of workers with shorter employment horizons can be the explanations.

At the same time, the services tend to play more significant role in modern economies. The industries like banking or lawyer services require more

10 Heywood, Jirjahn and Tsertsvardze (2008) also point to different situation of older workers in different countries. The opportunities for backloading compensation can be reduced by labour market regulation. For example, extensive employment protection in Germany decreases the risk to be fired because of low performance. Moreover, higher firing costs supress firms' willingness to hire older workers as they entail higher risk of sickness or out-of-date skills. Centrally set wages leads to flatter wage structure within the hierarchy and it results in smaller reward for tenure. Finally, deferred compensation is less needed in the case of high-bargained wages and higher unemployment. However, generous social system can decrease the cost of job loss and make deferred compensation more required.

11 Daniel and Heywood (2007) suggest that these advantages come with increased tenure within the firm. If older workers are separated from original firm then the cost of hiring can exceed their productivity. Moreover, Heywood and Siebert (2009) notice that workers acquire not only firm-specific skills but also accumulate managerial culture. If older workers are dismissed, the need to change such cultural knowledge can make them less attractive than new workers. 
experienced workers. If the skills acquired during working are more important that skills acquired in formal education than higher experienced workers can be more demanded (Gómez and de Cos, 2008). Increasing employment share in the service sector is also associated with reducing number activities requiring greater physical strength and stamina (Dalen, Henkens and Schippers, 2010). On the other side, the ageing will likely increase the demand for more labour-intensive services (Lindh and Malmberg, 2009). These services are often related to technological features that are distinct from large scale production. It could lead not only to lower productivity of economy but also lower employment of older workers.

Although older workers can face many challenges to stay competitive in the job market, we can see the increase of employment ratio of people aged 55 to 64. Fig. 1 shows that the share of employed older workers was rising in selected European countries (and in the EU as a whole) in the last decade. Surprisingly, the positive development of this measure was noticeable in all different types of advanced economies. Especially, the Czech Republic has experienced not only favourable economic growth and low unemployment rate but also relatively high increase in engagement of older workers.

\section{KEEPING OLDER WORKERS IN LABOUR MARKET}

There are many models trying to explain determinants of economic growth. Neoclassical theory emphasizes the size of labour force, the amount of disposable capital and used technology while endogenous growth models also suggest the importance of human capital. In general, the economic growth can be stimulated by shifting labour from less productive industries to more perspectives industries or by improvement of efficiency in the whole economy. Technological progress, human capital, institutional framework, economic policies or trade policies can play a significant roles too. There can also be the reverse effects from economic growth to technological progress and human capital accumulation which represents the key determinants of economic growth (Bloom, Canning and Fink, 2008).

The ageing directly effects real economy through changes in working population, savings and productivity. Carone et al. (2005) mention three separate channels of productivity. First, the quality of labour input that is affected both by age structure of society and by accumulated human capital of workers. Total factor productivity is also influenced by the share of capital to labour and by technological progress.

Because the older people tend to work and save less, the labour supply and available amount of capital are supposed to decline. In addition, lower savings could lead to higher interest rates, decline in investment and labour productivity (Onder and Pestieau, 2014). Aiyar, Ebeke and Shao (2016) find a significant negative effect of workforce ageing on labour productivity (and the real growth of output per worker). The main factor of reduced productivity is most likely lower TFP growth.

On the other side, the ageing can stimulate economic growth if people adjust their behaviour. (It means working longer and save more). And if more experienced workers decide to stay at work longer, the productivity of economy might not decline (The Economist, 2014). Carone et al. (2005) also suggest that the decrease in labour supply can stimulate the increase in wages and leads to the substitution of labour for capital. The increase in capital intensity might stimulate labour productivity a GDP per capita growth. And if the investment rate remains constant then the decrease in labour supply might lead to strong capital deepening in short and medium run. Finally, Börsch-Supan, Ludwig and Winter (2005) argue that if increase in wages exceeds the increase in capital returns then household can have lesser incentives to save. But the decrease in labour supply leads to reduction in demand of investment goods because less capital is needed. Thus the ageing should not have negative effects on total productivity.

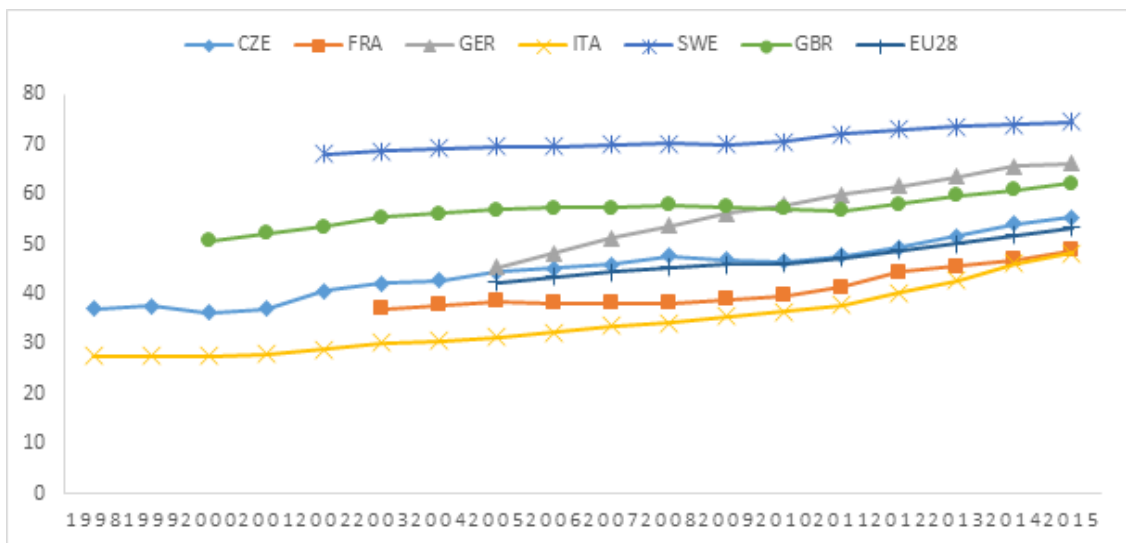

1: Employment ratio of people aged 55 to 64 (\% in the same age group) Source: OECD (2018) 
In addition, keeping older employees at work may be beneficial not only for performance of national economy but also for financial sustainability. (Working people don't receive pensions and pay taxes and contributions to social security system). Because ageing population is usually associated with increase in public spending, raising tax rates might be necessary to prevent large budget deficits. It could have negative effects on decision making of economic actors and suppress GDP growth. Feldstein (2006) argues that higher payroll taxes can lead in the short term to decline in hiring workers and employment rate. Over the time these taxes can result in lower hourly earnings and decrease in labour supply. Excessive taxation also discourage workers to acquire new skills through formal education and job training. Firms could be less motivated to invest into new plans and equipment too. If employees lower their effort and firms reduce capital accumulation then total factor productivity growth might be slower. The inactivity trap of workers can be according to Carone et al. (2005) induced by higher contributions to social security systems. If the reservation wage of exceeds net wage then some workers can be less motivated to find a job.

Expected adverse effects of ageing on economic performance can be reduced by structural reforms aiming at labour market flexibility, health care system, social security system and pension system. These reforms have to give larger role of part time jobs, create the incentives to participate in labour market, suppress the motivation to retire or increase the investment to improve workers' health (Bloom et al., 2008). As expected, if the workers are healthy in senior age, they tend to participate longer in labour markets (Börsch-Supan, 2013). Similarly, poor health and disability of older workers reduce probability to return to employment if they once lose their jobs (Chan and Stevens, 2001).

The effort to retain older workers in labour supply often requires eliminating labour market rigidity that make it difficult to choose desired trajectories from work to retirement. Blau and Shvydko (2007) emphasize lack of opportunity for part-time and flexible-hours work, low wages and lack of fringe benefits in the part-time employment opportunities and lack of training and promotion opportunities for older workers. Thus, labour market rigidity is likely important reason for prevalence of abrupt retirement. (The second one could be fixed time costs of employment faced by workers).

The labour market rigidity can be caused by restrictions on hours of work imposed by firms. ${ }^{12}$ Not only team production but also fixed costs of hiring, training and employing workers can play an important roles (Blau and Shvydko, 2007). Heywood and Siebert (2009) explain that both hiring/selecting workers to fill jobs and training the workers are associated with costs per head. Workers on part-time hours become more expensive because these costs are spread over fewer hours. ${ }^{13}$ According to Heywood and Siebert older workers, who prefer gradual retirement and move into part-time work, have to accept lower wages. Unfortunately, if the reduction in earnings is banned by anti-discrimination rules or wages are generally sticky, firms are reluctant to offer part-time jobs.

However, firms usually recognize experience and technical or firm-specific knowledge of older workers. But if these employees are separated from original firms, they lose their productivity advantage (Daniel and Heywood, 2007). Chan and Stevens (2001) also suggest that displacement can lead to reduction in both earnings prospects and attractiveness of continued work after displacement. According to Konle-Seidl (2017) firms are obliging to pay less to older workers because of assumed lower productivity and higher reservation wages. However, older workers tend to refuse starting salary below the wage before becoming unemployed. Unwillingness to accept the decrease in earning leads to rising risk of displacement because firms can consider longer period of unemployment as symptom of reduced productivity.

In addition, if the relative wages (of less qualified workers) decline then the retirement depending on mandatory benefits becomes more attractive. Moreover, mandatory benefits can stimulate unemployed workers to choose early retirement. The official retirement age and the amount of pensions might be important reasons for lower employment of senior workers (The Economist, 2009, 2014). Similarly, according to Heywood and Siebert (2009) the problem can be tax laws that prevent people working and receiving a pension and make little allowance for fair pension increases if retirement is deferred. The other reason for abrupt retirement, as Heywood and Siebert suggest, is employment protection laws. Naturally, raising firing costs of workers discourage firms from hiring older workers.

On the other side, Konle-Seidl (2017) highlights the need of pension reforms. Strengthening of financial incentives (or "financial penalties") by raising the statutory pensionable age, introducing actuarial deductions for early retirement and phasing out of country specific pathways to early retirement can be seen as an important measures for extending working lives. The flexibility to combine income from work and pension can play significant role too.

12 Because absence of team member can reduce firms' performance, employers might reduce part-time and flexi-time jobs and require presence of workers at specific times. Teamwork can both make harder for older people to undergo gradual retirement and lower their chances to get a job (Blau and Shvydko, 2007).

13 Heywood and Siebert (2009) also mention that countries with a high average retirement age tend to have also high rate of training of older workers relative to younger cohorts. 
Keeping older workers employed can also lead the firms to consider the demotion. But according to Van Dalen and Henkens (2015) it can both raise concerns of senior employees about loss of reputation and increase incentives to end careers because demotion may indicate the decline in performance. Other employees may consider demotion as a signal that implicit contracts (i.e. delayed compensation contracts) couldn't be fulfilled. Moreover, managers can be afraid of less effort, lower loyalty or work motivation.

Finally, there are factors pulling older workers into workforce while others push them into retirement. Chronical age, stability of financial resources, physical and mental well-being, satisfaction with work and the work environment or personal and family situation can play crucial roles (Pitt-Catsouphes and Smyer, 2005). In addition, raising demand for leisure, social security arrangements or the overall increase in wealth could lead to low participation of senior in labour markets (Bloom, Canning and Fink, 2011).

If we look at Fig. 2 we can notice rapid decline in the labour force participation rate of people 65 years and older until the end of the last century. Since then, the share of older people participating on the labour market isn't at least shrinking. Despite selected industrial countries have experienced moderate growth of this measure the participation rate of seniors in the work force still remains below the earlier rate. Thus governments need to find effective ways how to increase the involvement of seniors in productive life.

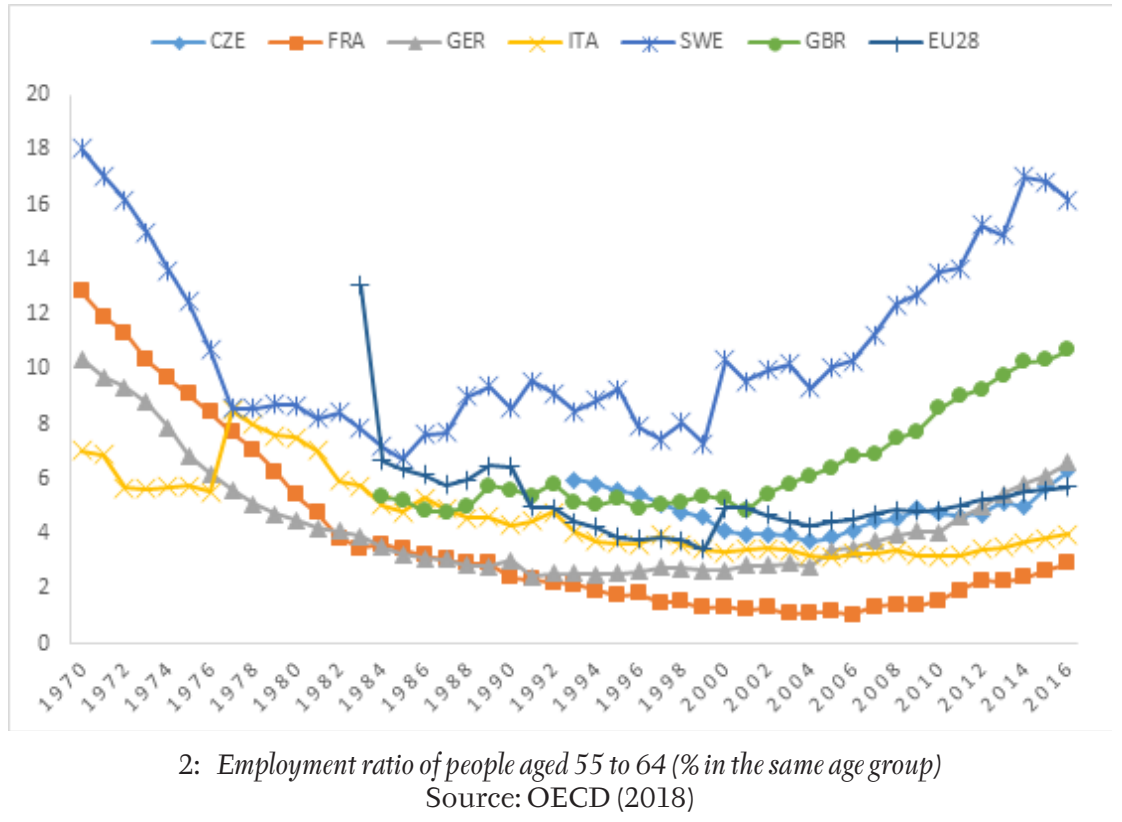

\section{CONCLUSION}

Standard economic theory suggests that wages should mirror the productivity of workers. However, it isn't easy to estimate labour productivity and its changes with age. In addition, there are other factors influencing both the performance of individual workers and their earnings. Actually, the productivity profile is likely upward sloping and concave but the wages don't often follow this development. Delayed compensation or theory of efficiency wages can be satisfactory explanations for observed differences between productivity and wages. As a result, the older workers face some difficulties on the labour markets. While firms are usually willing to employ older workers, they are also reluctant to hire them.

Technical progress and structural changes in national economies create risks as well as opportunities for older workers. We can identify a several suggestion how to mitigate negative effects of ageing. First, flexible labour market can significantly improve the prospects of older workers. For example, if the cognitive and physical abilities depreciate with age and if older workers are appreciated for their experience and firm specific skills or knowledge then adjustment of work tasks can help to extend working life. And if older workers prefer both more leisure time and to gradually reduce hours of work then part-time and flexi-time jobs can motivate workers to postpone retirement. Likewise, flexible wages make it easier to find a suitable job. And of course, better education, health or training opportunities can stimulate older employees to work longer. But other institutional changes, e.g. reforms of social security systems and pension systems, are also needed. Improving prospects for older workers requires incentives aimed at older workers as well as firms. 
We need to say that this article hasn't mentioned all relevant studies. It is also very difficult to cover all important factors influencing senior workers. We have presented main problems that older workers face in their careers. However, we weren't able to arrange these factors according to their importance. Moreover, the population ageing affects national economies in different ways and individual countries have special needs and priorities. This article didn't offer any universal strategy how to improve the prospects of older workers on labour markets.

The measures aimed at reducing obstacles for older workers should reflect the changes in productivity during their working life. We need to develop new and more suitable methods how to measure productivity on individual level as well as in the team work. More studies covering changes in both skills and cognitive capabilities of workers should be beneficial. It can help design proper policy measures and keep productivity stable. However, more interdisciplinary approach is necessary.

\section{Acknowledgment}

This article was written within the project LDI 15065 - Gender dimension of implementation of active ageing in Czech private and public sector and its comparison with western countries. This project was financially supported by MŠMT within the project COST CZ (LD).

\section{REFERENCES}

AIYAR, S., EBEKE, C. and SHAO, X. 2016. The Impact of Workforce Aging on European Productivity. IMF Working Paper 16/238. [Online]. Available at: https://www.imf.org/external/pubs/ft/wp/2016/wpl6238.pdf [Accessed: 2017, June 29].

AUBERT, P and CRÉPON, B. 2007. Are Older People Less Productive? Firm-Level Evidence on Age-Productivity and Age-Wage Profiles. [Online]. Available at: http://www.crest.fr/ckfinder/userfiles/files/pageperso/Age\%20 Wage\%20and\%20Productivity.doc [Accessed: 2017, June 29].

BEACH, C. M. 2008. Canada's Aging Workforce: Participation, Productivity, and Living Standards. Bank of Canada. [Online]. Available at: http://www.bankofcanada.ca/wp-content/uploads/2010/09/beach.pdf [Accessed: 2017, June 29].

BELBASE, A. and SANZENBACHER, G. 2016. Cognitive Aging and Ability to Work. Center for Retirement Research at Boston College. [Online]. Available at: http://crr.bc.edu/wp-content/uploads/2016/11/IB_1618.pdf [Accessed: 2017, June 29].

BLAU, D. M. and SHVYDKO, T. 2007. Labour Market Rigidities and the Employment of Older Workers. IZA Discussion Paper No. 2996. [Online]. Available at: http://ftp.iza.org/dp2996.pdf [Accessed: 2017, June 29].

BLOOM, D. E., CANNING, D. and FINK, G. 2008. Population Aging and Economic Growth. PGDA Working Paper No. 31. [Online]. Available at: https://cdnl.sph.harvard.edu/wp-content/uploads/sites/1288/2013/10/ PGDA_WP_31.pdf [Accessed: 2017, June 29].

BÖRSCH-SUPAN, A. 2013. Myths, science evidence and economic policy in ageing world. The Journal of Economics of Ageing, 1-2: 3-15.

BÖRSCH-SUPAN,A.,LUDWIG,A.andWINTER,J.2013.Aging,Pension Reform, and CapitalFlows: AMulti-Country Simulation Model. NBER Working Paper 11850. [Online]. Available at: http://www.nber.org/papers/w11850. pdf [Accessed: 2017, June 29].

CARONE, G., COSTELLO, D., GUARDIA, N. D. et al. 2005. The economic impact of ageing populations in the EU25 Member States. European Commission Directorate-General for Economic and Financial Affairs Publications. [Online]. Available at: http://ec.europa.eu/economy_finance/publications/pages/publication562_en.pdf [Accessed: 2017, June 29].

CHAN, S. and STEVENS, A. H. 2001. Job Loss and Employment of Older Workers. Journal of Labour Economics, 19(2): 484-521.

DANIEL, K. and HEYWOOD, J. S. 2007. The Determinants of hiring older workers: UK Evidence. Labour Economics, 14(1): 35-51.

DOSTIE, B. 2006. Wages, Productivity and Ageing. IZA Discussion Paper No. 2496 [Online]. Available at: http:// ftp.iza.org/dp2496.pdf [Accessed: 2017, June 29].

DOSTIE, B. 2011. Wages, Productivity and Ageing. De Economist, 159(2): 139-158

EUROPEAN COMMISSION. 2006. Ageing and Employment: Identification of Good Practice To Increase Job Opportunities and Maintain Older Workers in Employment (Final Report). [Online]. Available at: http://ec.europa. eu/social/BlobServlet?docId=214\&langId=en [Accessed: 2017, June 29].

FELDSTEIN, M. S. 2006. The Effects of the Ageing European Population on Economic Growth and Budgets: Implications for Immigration and Other Policies. NBER Working Paper 12736. [Online]. Available at: http://www.nber.org/ papers/w12736.pdf [Accessed: 2017, June 29].

GÖBEL, Ch. and ZWICK, T. 2013. Are personnel measures effective in increasing productivity of old workers? Labour Economics, 22(C): 80-93

GÓMEZ, R. and De COS, P. H. 2008. Does Population Ageing Promote Faster Economic Growth? Review of Income and Health, 54(3): 351-372 
GORDO, L. R. and SKIRBEKK, V. 2013. Skill demand and the comparative advantage of age: Jobs tasks earnings from the 1980s to the 2000s in Germany. Labour Economics, 22: 61-69.

H/ÆGELAND, T. and KLETTE, T. J. 1999. Do Higher Wages Reflect Higher Productivity? Education, Gender and Experience Premiums in a Matched Plant-Worker Data Set. Statistics Norway Discussion Papers No. 208. [Online]. Available at: http://www.ssb.no/a/publikasjoner/pdf/DP/dp_208.pdf [Accessed: 2017, June 29].

HELLERSTEIN, J. K. and NEUMARK, D. 1995. Are Earnings Profile Steeper Than Productivity Profiles? Evidence from Israeli Firm Level Data. The Journal of Human Resources, 30(1): 89-112.

HELLERSTEIN, J. K. and NEUMARK, D. 2004. Production Function and Wage Equation Estimation with Heterogeneous Labor: Evidence from a New Matched Employer-Employee Data Set. NBER Working Paper 10325. [Online]. Available at: http://www.nber.org/papers/w10325.pdf [Accessed: 2017, June 29].

HELLERSTEIN, J. K., NEUMARK, D. and TROSKE, K. R. 1999. Wages, Productivity, and Workers Characteristics: Evidence from Plant-Level Production Functions and Wage Equations. Journal of Labor Economics, 17(3): 409-446.

HEYWOOD, J. S. and JIRJAHN, U. 2016. The Hiring and Employment of Older Workers in Germany: A comparative perspective. Journal for Labour Market Research. 49(4): 349-366.

HEYWOOD, J. S., JIRJAHN, U. and TSERTSVARDZE, G. 2008. Hiring older workers and employing older workers: German evidence. Journal of Population Economics, 23(2): 595-615.

HEYWOOD, J. S. and SIEBERT, W. S. 2009. Understanding the Labour Market for Older Workers: A Survey. IZA Discussion Paper No. 4033. [Online]. Available at: http://ftp.iza.org/dp4033.pdf [Accessed: 2017, June 29].

KONLE-SEIDL, R. 2017. Retention and Re-integration of older workers into the labour market: What works? IAB Discussion Paper 17/2017. [Online]. Available at: http://doku.iab.de/discussionpapers/2017/dp1717.pdf [Accessed: 2017, June 29].

LALLEMAND, T. and RYCX, F. 2009. Are Young and Old Workers Harmful for Firm Productivity? IZA Discussion Paper No. 3938 [Online]. Available at: http://ftp.iza.org/dp3938.pdf [Accessed: 2017, June 29].

LINDH, T. and MALMERG, B. 2009. EU Economic Growth and the Age Structure of the Population. Economic Change and Restructuring, 42(3): 159-187

MAHLBERG, B., FREUND, I., CUARESMA, J. C., and PRSKAWETZ, A. 2013. Ageing productivity and wages in Austria. Labour Economics, 22(100): 5-15.

MEDOFF, J. L. and ABRAHAM, K. G. 1980. Experience, Performance and Earnings. The Quarterly Journal of Economics, 95(4): 703-736.

NATIONAL RESEARCH COUNCIL. 2012. Ageing and the Macroeconomy: Long-Term Implication of an Older Population. The National Academies Press. [Online]. Washington: The National Academies Press. Available at: http://pages.stern.nyu.edu/ dbackus/BCH/demography/NAS_aging_12.pdf [Accessed:2017, June 29].

ONDER, H. and PESTIEAU, P. 2014. Is Aging Bad for the Economy?Maybe. The World Bank. [Online]. Available at: http://documents.worldbank.org/curated/en/898291468335680929/pdf/882210BRIOEP1440Box3852 12B00PUBLIC0.pdf [Accessed: 2017, June 29].

PITT-CATSOUPHES, M. and SMYER, M. A. 2005. Older Workers: What Keeps Them Working? Sloan Center on Aging \& Work at Boston College. [Online]. Available at: https://dlib.bc.edu/islandora/object/bc-ir:100893/ datastream/PDF/view [Accessed: 2017, June 29].

SKIRBEKK, V. 2003. Age and Individual Productivity: A Literature Survey. MPIDR Working Paper WP 2003-028 [Online]. Available at: http://www.demogr.mpg.de/papers/working/wp-2003-028.pdf [Accessed: 2017, June 29].

SKIRBEKK, V. 2008. Age and Productivity Capacity: Descriptions, Causes and Policy Options. Ageing Horizons, 8: 4-14.

TANG, J. and MACLEOD, C. 2006. Labour force ageing and productivity in Canada. Canadian Journal of Economics, 39(2): 582-603

THE ECONOMIST. 2009. A slow-burning fuse: A special report on ageing populations. The Economist, 27th June 2009.

THE ECONOMIST. 2014. Age invaders. The Economist, 26th April 2014.

VAN DALEN, H. P. and HENKENS, K. 2015. Why Demotion of Older Workers Is A No-Go Area for Managers. CentER Discussion Paper No. 2015-025. [Online]. Available at: https://pure.uvt.nl/ws/files/5712390/2015_025.pdf [Accessed: 2017, June 29].

VAN DALEN, H. P., HENKENS, K. and SCHIPPERS, J. 2010. Productivity of Older Workers: Perceptions of Employers and Employees. Population and Development Review, 36(2): 309-330.

VAN OURS, J. 2009. Will You Still Need Me: When I'M 64? De Economist, 157(4): 441-460.

VAN OURS, J. and STOELDRAJER, L. 2011. Age, Wage and Productivity in Dutch Manufacturing. De Economist, 159(2): 119-137.

WERDING, M. 2008. Ageing And Productivity Growth: Are There Macro-Level Cohorts Effects of Human Capital? [Online]. Available at: http://www.cesifo-group.de/portal/page/portal/DocBase_Content/WP/WP-CESifo_ Working_Papers/wp-cesifo-2008/wp-cesifo-2008-01/cesifol_wp2207.pdf [Accessed: 2017, June 29]. 


\section{Contact information}

Pavel Breinek: breinek@node.mendelu.cz 